\title{
Pluripotency in the Embryo and in Culture
}

\author{
Jennifer Nichols ${ }^{1,2}$ and Austin Smith ${ }^{1,3}$ \\ ${ }^{1}$ Wellcome Trust Centre for Stem Cell Research, Stem Cell Institute University of Cambridge, Cambridge CB2 1QR, \\ United Kingdom \\ ${ }^{2}$ Department of Physiology, Development and Neuroscience, University of Cambridge, Cambridge CB2 1QR, \\ United Kingdom \\ ${ }^{3}$ Department of Biochemistry, University of Cambridge, Cambridge CB2 1QR, United Kingdom \\ Correspondence: ags39@cam.ac.uk
}

\section{SUMMARY}

Specific cells within the early mammalian embryo have the capacity to generate all somatic lineages plus the germline. This property of pluripotency is confined to the epiblast, a transient tissue that persists for only a few days. In vitro, however, pluripotency can be maintained indefinitely through derivation of stem cell lines. Pluripotent stem cells established from the newly formed epiblast are known as embryonic stem cells (ESCs), whereas those generated from later stages are called postimplantation epiblast stem cells (EpiSCs). These different classes of pluripotent stem cell have distinct culture requirements and gene expression programs, likely reflecting the dynamic development of the epiblast in the embryo. In this chapter we review current understanding of how the epiblast forms and relate this to the properties of derivative stem cells. We discuss whether ESCs and EpiSCs are true counterparts of different phases of epiblast development or are culture-generated phenomena. We also consider the proposition that early epiblast cells and ESCs may represent a naïve ground state without any prespecification of lineage choice, whereas later epiblasts and EpiSCs may be primed in favor of particular fates.

\section{Outline}

1 Introduction

2 Formation of the blastocyst

3 Derivation of ESCs

4 EGG cylinder development and EpiSCs

5 Refined conditions for ESC propagation and development of " $2 \mathrm{i}$ "

6 A transcription factor network that sustains naïve pluripotency
7 Exploiting embryonic transcription factors to convert somatic cells to pluripotency

8 Human pluripotent stem cells

9 Concluding remarks

References

Editors: Patrick P.L. Tam, W. James Nelson, and Janet Rossant

Additional Perspectives on Mammalian Development available at www.cshperspectives.org

Copyright (C 2012 Cold Spring Harbor Laboratory Press; all rights reserved; doi: 10.1101/cshperspect.a008128

Cite this article as Cold Spring Harb Perspect Biol 2012;4:a008128 


\section{INTRODUCTION}

Embryogenesis is often considered as a progressive loss of developmental capacity from a "totipotent" zygote. In reality, however, the mammalian egg is a highly specialized and restricted cell. It is programmed to undergo a stereotyped process of cleavage divisions that accomplishes the oocyte-to-embryo transition (Selwood and Johnson 2006). Developmental potential is unlocked through formation of the epiblast cells in the inner cell mass (ICM) of the blastocyst. The notion that pluripotency is an emergent property that is realized in the epiblast is consistent with molecular analyses, notably expression patterns of critical transcription factors that are not present in the zygote. Newly formed epiblast cells are believed to have equivalent capacity to generate all somatic lineages of the embryo and the germline. They might therefore be considered "naïve." In mice and rats, cells from the naïve epiblast can be propagated in vitro. These embryonic stem cells (ESCs) retain similar, if not identical, properties to the epiblast. They selfrenew or differentiate into multiple tissue types, depending on the conditions of the in vitro environment. Most remarkably, they are able to participate in normal development when returned to the early embryo, even after extensive proliferation in vitro. Of particular note, ESCs can give rise to functional gametes and have therefore been used extensively to create genetically engineered lines of mice for developmental, genetic, and biomedical research $(\mathrm{Ca}-$ pecchi 2005). We review this evidence and the associated proposition that cells of the naïve epiblast and ESCs represent a developmental ground state for mammals. The epiblast is not a fixed state, however. Epiblast cells are subjected to specification signals from extraembryonic tissues preparatory to gastrulation (Beddington and Robertson 1999). Their naive status may therefore be eroded even though they are not yet lineage committed. We contrast ESCs with pluripotent stem cells known as postimplantation epiblast stem cells (EpiSCs) that originate from this developmentally more advanced epiblast.

\section{FORMATION OF THE BLASTOCYST}

The mammalian embryo begins development packaged within the zona pellucida, a glycoprotein protective layer surrounding the oocyte. Cleavage divisions generate a cluster of cells known as blastomeres. In the mouse, differentiation initiates at the eight-cell stage with the onset of polarization of the outside cells. Microvilli appear on the apical surfaces and cytoplasmic microtubules and organelles become apicobasally distributed (Ducibella and Anderson 1975). The blastomeres then become closely apposed with one another in a cellular process called compaction.
Subsequent cell divisions result in the complete envelopment of some cells, which remain apolar, whereas the polar cells stay on the outside and develop into an epithelial layer, the trophoblast (Johnson and Ziomek 1981). Until the trophoblast and inner cells are fully segregated spatially, cells can be repositioned and will acquire the characteristics of cells in the new location (Tarkowski and Wroblewska 1967). This observation exemplifies both the regulative nature of the developing mammalian embryo and the progressive manner of lineage differentiation.

Specification of the trophoblast lineage appears to be mediated primarily by regionalized activity of the transcription factor Tead4 in the cleavage-stage embryo (Nishioka et al. 2009). Tead4 is active in the outside cells when the Hippo pathway is inactive but is inactivated in the inside cells (ICM) that perceive signaling through the Hippo pathway elicited by changes in cell contact and cell morphology (Wada et al. 2011). Tead4 up-regulates the caudal-type homeobox transcription factor Cdx2 and the T-box transcription factor eomesodermin, which drive commitment to the trophoblast lineage. A positive-feedback loop operates via the Ets-domain transcription factor Elf5 ( $\mathrm{Ng}$ et al. 2008). Methylation of the Elf5 gene in ICM cells may provide an epigenetic barrier to subsequent trophoblast commitment.

Diversification of the trophoblast and ICM defines the progression of the embryo from the morula to the blastocyst stage of development. Coincident with specification of the trophoblast, the inside cells acquire a reciprocal expression profile of key transcription factors. They lose Tead4, $\mathrm{Cdx} 2$, and eomesodermin, but maintain the POU-domain transcription factor Oct4 (Pou5f1), which is down-regulated in the trophoblast. Oct4 is essential to establish the distinct identity of the ICM. In the absence of Oct4, inside cells form but are unable to develop ICM character and eventually differentiate along the trophoblast lineage (Nichols et al. 1998). Consequently, although mutant embryos can implant in the uterus, they do not develop any embryonic rudiment. Oct4 often acts cooperatively with the SRY-boxcontaining transcription factor Sox 2 to regulate expression of multiple target genes, including fibroblast growth factor4 (FGF4) (Basilico et al. 1997) and key transcription factors such as Nanog (Boyer et al. 2005). Sox2-null embryos do form normal blastocysts but fail development before gastrulation (Avilion et al. 2003). A requirement for embryo-derived Sox 2 in the ICM is believed to be masked by long-lived maternally encoded protein, although this has yet to be tested by ablation of the maternal gene product.

Trophoblast cells transfer fluid into the blastocyst to form a cavity, the blastocoel. After cavitation the ICM becomes partitioned into epiblast and hypoblast (also known as the "primitive endoderm"). In the mature blastocyst 


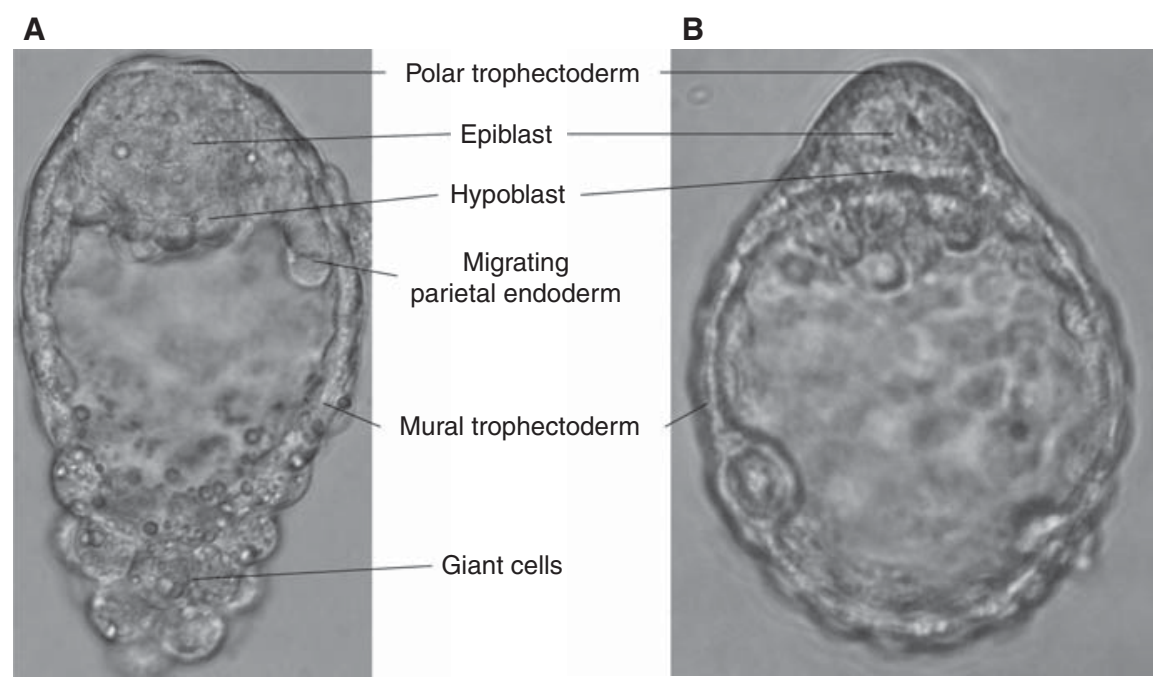

Figure 1. Bright field images of mature mouse blastocysts showing morphological segregation of epiblast and hypoblast before implantation in the uterus. (A) Peri-implantation at E4.5; (B) diapause. Embryos were freshly flushed from uteri and images captured on an Olympus IX50, with a magnification of $200 \times$.

(Fig. 1A), the hypoblast is morphologically distinguishable as an epithelium overlying the blastocoelic surface of the ICM. The specification of epiblast versus hypoblast is still not fully understood. Genetic manipulations in ESCs suggested that the two transcription factors Nanog and Gata6 may act in a mutually antagonistic manner to determine the two lineages. In the embryo, however, Nanog and Gata6 both begin to be expressed in an apparently stochastic manner at around the eight-cell stage (Dietrich and Hiiragi 2007), and they can be colocalized in some cells of the ICM at least until the 32-cell stage (Plusa et al. 2008). Hypoblast markers, such as platelet-derived growth factor receptor $\alpha$ (PDGFR $\alpha)$ and Sox17, also initially show heterogeneous expression in the early blastocyst. Cells expressing these markers appear to sort out from Nanog-positive cells and if they end up located adjacent to the cavity will up-regulate additional transcriptional determinants Gata4 and Sox7 and become committed to hypoblast differentiation (Artus et al. 2011).

Formation of the epiblast is characterized by, and appears dependent on, expression of Nanog. Nanog protein is initially found at varying levels throughout the ICM (Dietrich and Hiiragi 2007; Plusa et al. 2008). By the late blastocyst stage, however, Nanog is precisely restricted to the new-formed epiblast, where it is present at similar levels in all cells. In female mouse embryos, reactivation of the silent paternal X chromosome occurs only in the Nanogpositive epiblast. Nanog-null embryos fail to establish epiblast identity because of degeneration of the ICM (Mitsui et al. 2003; Silva et al. 2009). X reactivation does not occur in these mutants, reflecting the absence of epiblast. Unexpectedly, the hypoblast is also lost even though Nanog is not expressed in this lineage. Nanog-null hypoblast cells can be rescued by wild-type cells in chimeras, demonstrating a non-cell-autonomous requirement (Messerschmidt and Kemler 2010). Hypoblast development thus depends on paracrine signaling from the epiblast. Such interaction may provide a means for regulating the relative numbers of hypoblast versus epiblast cells. FGF4 is the principal candidate for a paracrine factor. Genetic deletion of Grb2, which couples the FGF receptor to the mitogen-activated protein kinase/extracellular signal-regulated kinase (MAPK/ Erk) pathway, results in blastocysts that lack hypoblast (Cheng et al. 1998; Chazaud et al. 2006). Chemical inhibition of the FGF/Erk pathway in cultured embryos gives blastocysts in which all ICM cells become Nanog-positive epiblast (Nichols et al. 2009b; Yamanaka et al. 2010). This occurs by suppression of hypoblast specification such that all cells are converted to epiblast. Conversely, administering high concentrations of FGF4 to early embryos can drive the entire ICM to form hypoblast (Yamanaka et al. 2010). The segregation of the two lineages may be consolidated by reciprocal expression of FGF receptor in the hypoblast and FGF4 in the epiblast (Guo et al. 2010).

\section{DERIVATION OF ESCS}

ESCs were first derived by explanting blastocysts or ICMs on a layer of "feeder" cells (mitotically inactivated fibroblasts) in medium containing fetal calf serum (Evans and Kaufman 1981; Martin 1981). These supportive requirements had been determined empirically using pluripotent embryonal carcinoma (EC) cells (Martin and Evans 1975). They are sufficient to support unlimited expansion of 
undifferentiated EC cells or ESCs. Like EC cells, ESCs form multidifferentiated teratocarcinomas when grafted to adult mice. Their full potency is revealed by blastocyst injection. This yields chimeric mice with extensive contribution from the injected ESC progeny to all tissues, including functional colonization of the germline (Fig. 2) (Bradley et al. 1984). Using embryo aggregation or tetraploid hosts, it is now possible to derive liveborn mice that are apparently entirely composed of ESC derivatives (Nagy et al. 1990, 1993). ESCs thus show an unprecedented developmental capacity after prolonged in vitro culture. Furthermore, ESC chimeras do not develop tumors. The continuous self-renewal that enables expansion in culture must be rapidly extinguished when ESCs are returned to the embryonic environment, but precisely how and when this occurs has not been defined.

Interestingly, Evans and Kaufman used embryos in diapause for their ESC derivations (Evans and Kaufman 1981). Diapause is a condition of embryo arrest at the peri-implantation blastocyst stage (see Fig. 1B). This occurs when implantation is prevented by estrogen deprivation consequent to persistent suckling, ovariectomy, or administration of an estrogen antagonist, such as tamoxifen. Blastocysts hatch from the zona pellucida, segregate hypoblast and epiblast, and then remain paused for up to several weeks because the uterus is unreceptive. When estrogen is restored, implantation can proceed and normal embryogenesis ensues. Diapause facilitates derivation of ESCs (Evans and Kaufman 1981; Brook and Gardner 1997), possibly because it synchronizes embryos at the naïve epiblast stage. Although development is suspended, the cell number

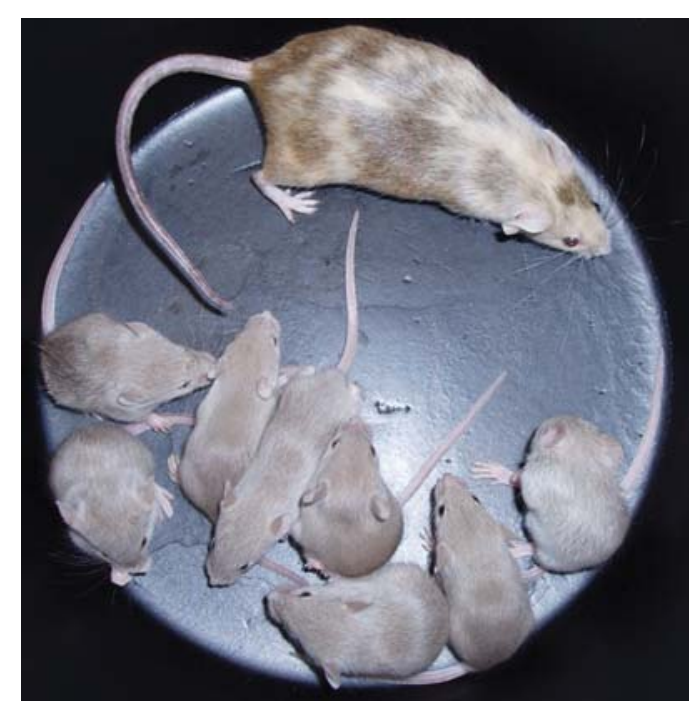

Figure 2. Adult male mouse ESC chimera generated by injection of 129/Ola ESCs (sandy coat color) into a C57BL/6 blastocyst (black coat color), with pups produced by mating of the chimera to a wildtype albino MF1 female. The gray color of the pups indicates that the sperm arose from colonization of the germline by the injected ESCs. in the ICM increases slightly during diapause (Nichols et al. 2001), implying that the cells continue to cycle. This is a situation therefore when epiblast cells may undergo selfrenewal in vivo (Smith 2001).

The traditional regime for ESC derivation is to explant intact blastocysts or immunosurgically isolated whole ICMs. ESC lines have also been established from single cells isolated following epiblast microdissection (Brook and Gardner 1997). That study provided definitive evidence that ESCs originate from the mouse epiblast at embryonic day 4.5 (E4.5). Furthermore, by removing the extraembryonic tissues completely, the investigators reported that the efficiency of ESC derivation was increased. This technique requires specialist expertise, however, and has not been widely adopted. Successful derivations have also been reported from morulae and even from isolated eight-cellstage blastomeres, leading to the suggestion that ESCs might represent a very early stage of development (Eistetter 1992; Tesar 2005). In these studies, however, cultures are invariably left intact for several days. This may allow for developmental progression and cellular interactions that specify epiblast even if formation of an overt blastocyst is not apparent. Significantly, all mouse ESCs characterized to date show similar molecular and developmental phenotypes. There is currently no evidence that a distinct preepiblast cell state can be expanded.

\section{EGG CYLINDER DEVELOPMENT AND EpiSCs}

For implantation mouse embryos distribute along the length of the two uterine horns, associated with regionalized expression of epidermal growth factor (EGF) receptors in the uterus (Brown et al. 1989; Das et al. 1994). Physical contact initiates a localized decidual response in the uterus, and the embryo becomes directionally embedded in the deciduum. The giant cells of the mural trophoblast attach to a central crypt opposite the uterine mesometrium. The diploid polar trophoblast overlying the epiblast proliferates and forms the extraembryonic ectoderm. Meanwhile, the polar trophoblast derivatives overlying the extraembryonic ectoderm undergo giant cell transformation to form the ectoplacental cone. This contacts the mesometrial side of the uterus and initiates formation of the placenta. Hypoblast-derived parietal endoderm cells disperse along the inside surface of the mural trophoblast and secrete a thick basement layer known as Reichert's membrane. Hypoblast cells that maintain contact with the epiblast or extraembryonic ectoderm maintain an epithelial architecture and form the embryonic and extraembryonic visceral endoderm, respectively (Fig. 3). In addition to a nutritive function, the visceral endoderm is the source of regionalized signaling activity that is essential for patterning the embryo 
before and during gastrulation (Beddington and Robertson 1999).

After implantation the embryo is physically constrained and the continued growth of the epiblast is accommodated by its displacement into the blastocyst cavity. At this time the epiblast transforms within 12 hours from a compact cluster of cells (Fig. 3A) into a cup of columnar epithelium (Fig. 3B). The resulting structure is known as the egg cylinder. Epithelialization of the epiblast is believed to be regulated by both diffusible and cell-contact-dependent signals from the visceral endoderm (Coucouvanis and Martin 1995, 1999). It should be noted, however, that formation of the egg cylinder is a morphogenetic process unique to rodent embryos. In other mammals, including primates, the epiblast develops as a flat epithelial disk. This topological difference may influence the regulatory mechanisms that mediate progression from naïve pluripotency (Nichols and Smith 2009).

In addition to the clear morphological differences, preand postimplantation epiblast differ at the molecular level, for example, in the reciprocal expression of Rex1 (Zfp42) and FGF5 (Pelton et al. 2002). Furthermore, contribution of postimplantation epiblast cells to blastocyst chimeras has never been reported. It is not clear if this is because their cell-adhesion properties are incompatible with physical incorporation into the ICM or because they have lost competence to respond to developmental cues in the blastocyst. Egg cylinder epiblast does have the capacity to give rise to teratocarcinomas and EC cells, however (Solter et al. 1970; Stevens 1970). Moreover, lineage tracing using vital dye labeling of single cells during early gastrulation ex vivo reveals progeny in all three germ layers (Lawson et al. 1991), and egg cylinder epiblasts can be induced to form primordial germ cells at high efficiency (Hayashi et al. 2011). Clearly, therefore, postimplantation epiblast cells are pluripotent.

Attempts to derive ESCs directly from postimplantation epiblasts met with repeated failure. However, cell lines that show pluripotent features have now been derived using different culture conditions (Brons et al. 2007; Tesar et al. 2007). These postimplantation epiblast-derived stem cells, or EpiSCs, can generate teratocarcinomas but do not contribute effectively to blastocyst chimeras. EpiSCs express Oct4 but have reduced or no expression of Rex 1 and several other transcription factors expressed in ESCs. Compared with ESCs they show higher expression of factors present in the postimplantation epiblast, such as FGF5 and Brachyury. EpiSCs share with ESCs a large nuclear-to-cytoplasmic ratio and prominent nucleoli, but their morphology is more two-dimensional and epithelial. They do not survive efficiently as isolated single cells and do not respond to ESC culture conditions, but instead are dependent on FGF2 and activin. Strikingly, EpiSC lines differ

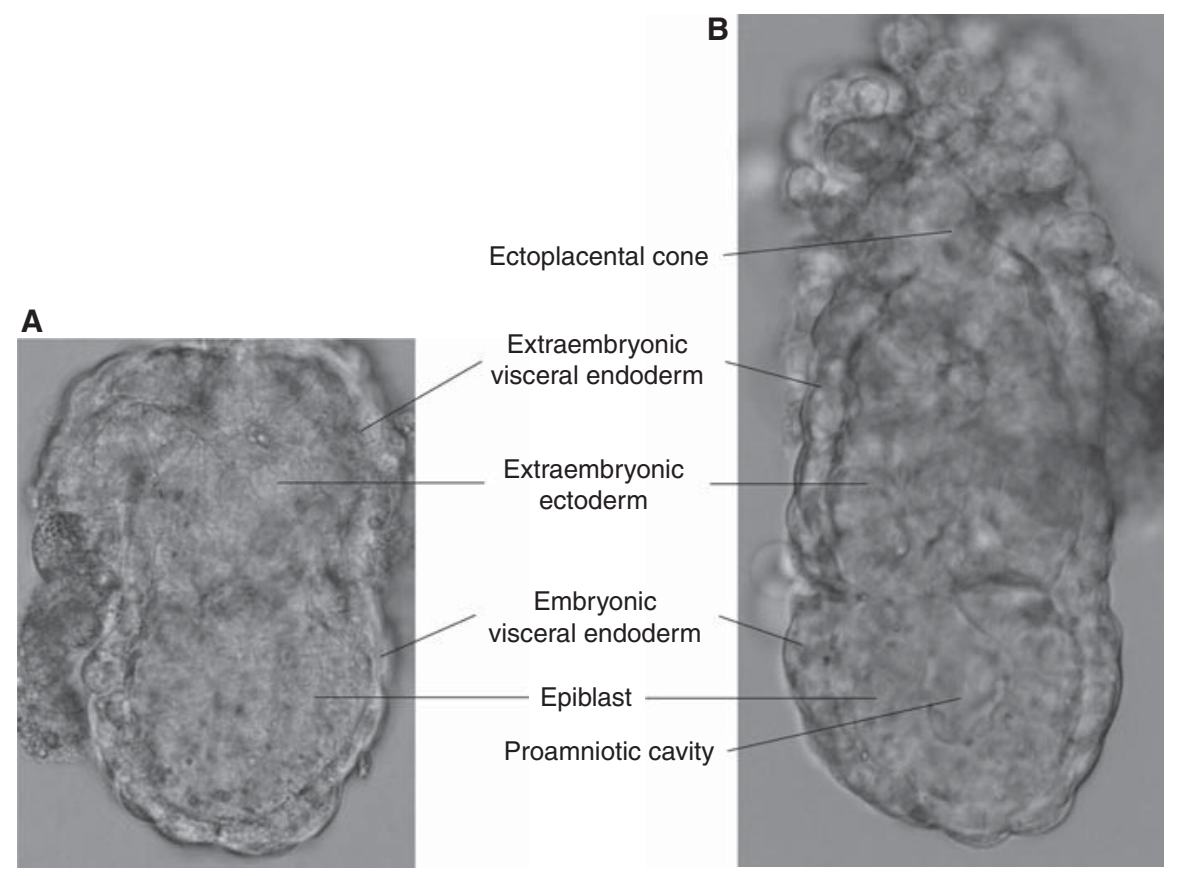

Figure 3. Bright field images of embryos just before and after epithelialization of the mouse epiblast at around E5.25. (A) The epiblast is still a compact ball. (B) The epiblast has epithelialized to form a cup-shaped structure and displays a prominent proamniotic cavity. Embryos were freshly dissected free from uteri, deciduum, and Reichert's membrane and images captured on an Olympus IX50, with a magnification of $200 \times$. 
markedly from one another, showing different differentiation biases (Bernemann et al. 2011). This variability could reflect heterogeneity within the egg cylinder. Alternatively, however, variability could arise from independent adaptations to the culture environment. Caution should therefore be exercised before considering EpiSCs as models of postimplantation epiblast cells. A key test will be to determine whether EpiSCs can engraft postimplantation epiblast in whole-embryo cultures.

Intriguingly, although most EpiSCs are clearly distinct from ESCs, some lines appear to harbor a subpopulation of cells that are more closely related (Han et al. 2010). If cultured to high density on feeder cells in the presence of leukemia inhibitory factor (LIF) and serum or transferred into 2i (see below) and LIF, such EpiSCs may spontaneously generate ESCs at low frequency (Hayashi and Surani 2009; Bernemann et al. 2011).

It has also been reported that ESC-like cell lines have been generated from dissociated postimplantation epiblasts following extended culture on feeder cells in medium supplemented with serum and LIF (Bao et al. 2009). Whether these cells arise directly from epiblast or via EpiSCs is uncertain. Another possibility is that they could develop via early germ cells. Primordial germ cells from early somite-stage embryos or isolated from genital ridges can convert in culture into pluripotent stem cells known as embryonic germ (EG) cells (Matsui et al. 1992; Resnick et al. 1992). Once established, EG cells are indistinguishable from ESCs apart from a variable degree of imprint erasure.

There is an intimate connection between the germline and pluripotency in mammals. Similar to primordial germ cells, it is possible to convert spermatogonial stem cells into pluripotent stem cells by exposing them to an appropriate regime of in vitro stimuli (Kanatsu-Shinohara et al. 2004; Ko et al. 2009). Indeed, it has even been suggested that all ESCs could be derived via germ cells (Zwaka and Thomson 2005). However, although germ cell specification might conceivably occur in ICM explants, this is not routinely observed. Furthermore, the high efficiency of establishing ESCs from early epiblast compared with a single report of derivation from postimplantation epiblast (Bao et al. 2009), which should more readily generate germ cell precursors, argues against this notion (Nichols and Smith 2011). Finally, derivation of ESCs from embryos lacking the essential germ cell determinant Blimp1 undermines the case for an obligatory germ cell intermediate (Chu et al. 2011).

\section{REFINED CONDITIONS FOR ESC PROPAGATION AND DEVELOPMENT OF "2i"}

Culture of established ESCs on feeder layers is still favored by many researchers because this provides a robust en- vironment for gene-targeting manipulations (Capecchi 2005). However, the derivation of mouse ESCs using feeders and serum is inefficient and variable, even from genetically identical inbred strains. Furthermore, the genetic background has a major influence on the capacity to give rise to ESCs. Until recently almost all the ESC lines in common use came from the 129 strain. It may be relevant that strain 129 males show an increased incidence of testicular teratocarcinomas. Unfortunately, however, these mice are generally poor breeders, perform inadequately in behavioral and cognitive studies, and are suboptimal for hematological and immunological research. Time-consuming back-crossing is often required to generate useful mouse models from the progeny of genetically modified 129 ESCs. Using the conventional culture regime, ESCs cannot reliably be derived from many important strains, such as FVB or nonobese diabetic (NOD) mice. Moreover, the derivation of ESCs from other species has not been successful, with the particular exception of certain primates (see below).

To exploit the full potential of ESCs and to clarify their relationship to cells in the mammalian embryo, it was necessary to refine the culture conditions and elucidate the molecular requirements for self-renewal. It was found that feeder cells could be replaced by a factor in conditioned medium (Smith and Hooper 1983, 1987; Koopman and Cotton 1984), later identified as the cytokine LIF (Smith et al. 1988; Williams et al. 1988). Germline-competent ESCs can be derived de novo using LIF instead of feeders (Nichols et al. 1990; Pease et al. 1990), but limited to the 129 strain. The subsequent replacement of serum with bone morphogenetic factor-4 (BMP4) (Ying et al. 2003) supported propagation of ESCs from several strains, although the de novo derivation of ESCs using just BMP and LIF appears limited to the 129 background (Ying et al. 2003).

LIF promotes ESC self-renewal by activation of the transcription factor Stat3 (Niwa et al. 1998; Matsuda et al. 1999). However, LIFalso stimulates the MAPK/Erk pathway, which acts to promote differentiation (Burdon et al. 1999). A more potent activator of Erk is FGF4, which is expressed by both epiblast and ESCs (Kunath et al. 2007). Genetic disruption or pharmacological inhibition of Erk signaling reduces differentiation in ESC cultures (Burdon et al. 1999; Kunath et al. 2007). Inhibition of this pathway increases persistence of Oct4-positive cells in primary explants during ESC derivation (Buehr and Smith 2003). In combination with LIF and BMP4, this enables ESC derivation from embryos of C57BL/6 and CBA strains in serum- and feeder-free culture conditions (Batlle-Morera et al. 2008).

Although FGF4/Erk stimulation is a major trigger for ESC differentiation (Kunath et al. 2007; Stavridis et al. 2007), Erk pathway inhibition alone is insufficient to support undifferentiated ESC expansion unless the cells are 
maintained at high densities or provided with LIF (Ying et al. 2008). Parallel studies had indicated that inhibition of another enzyme, glycogen synthase kinase-3 (GSK3), could enhance ESC self-renewal (Sato et al. 2004; Cartwright et al. 2005; Ogawa et al. 2006). Addition of a selective inhibitor of GSK3, CH99021, "rescued" ESCs in which Erk signaling was blocked (Ying et al. 2008). Using a combination of three inhibitors, known as "3i," comprising an FGF receptor inhibitor, an inhibitor of MAPK kinase (Mek) $1 / 2$, and the GSK3 inhibitor, robust ESC self-renewal is obtained in the absence of serum or LIF. This system allows ESCs to be derived from embryos of various strains of mice with high efficiency (Ying et al. 2008; Nichols et al. 2009a; Kiyonari et al. 2010; Yamagata et al. 2010). Female cell lines, which are underrepresented among serum-derived ESCs for unknown reasons, are readily obtained using $3 \mathrm{i}$ (Nichols et al. 2009a; Kiyonari et al. 2010). The operational activity of the FGF receptor in driving ESC commitment is via the Erk pathway. Accordingly, use of a Mek inhibitor (PD0325901) with high potency and selectivity eliminates the need to block the FGF receptor. Hence, 3i evolved into 2i (Wray et al. 2010).

It is important to note that the optimal concentration of CHIR99021 for mouse ESCs, $3 \mu \mathrm{M}$, only partially inhibits GSK3 (Ying et al. 2008). GSK3 inhibition relieves negative regulation of multiple proteins. Pinpointing the critical target(s) in ESC self-renewal therefore presented a challenge. However, a major suspect was $\beta$-catenin. Recent studies have confirmed that the effect of CHIR99021 is dependent on $\beta$-catenin and is largely reproduced by ablation of the $\beta$-catenin interactor Tcf3 (Wray et al. 2011; Yi et al. 2011). Tcf3 acts as a repressor of core pluripotency factors (Pereira et al. 2006; Cole et al. 2008), and deletion of Tcf3 suppresses ESC differentiation (Guo et al. 2011). Inhibition of GSK3 leads to stabilization of intracellular $\beta$ catenin, which interacts with Tcf3 to abrogate its repressor function (Wray et al. 2011). It is suggested that canonical Wnt signaling, which operates through $\beta$-catenin, may play a similar role in the blastocyst (Berge et al. 2011), but this remains uncertain in the absence of supporting genetic evidence (Merrill et al. 2004). Moreover, the canonical $\mathrm{Wnt} / \beta$-catenin pathway is a major inducer of axis formation and mesoderm differentiation in both the early embryo and ESC-derived embryoid bodies (ten Berge et al. 2008), which would imply a radical switch in function. The relative levels of different Tcfs may change in the late epiblast, but it also seems likely that Tcf3 may be regulated by pathways other than Wnt (Sokol 2011).

\section{A TRANSCRIPTION FACTOR NETWORK THAT SUSTAINS NAÏVE PLURIPOTENCY}

The ESC state is characterized by a unique network of transcription factors (Niwa 2007; Jaenisch and Young 2008). Table 1 lists key factors that have been functionally validated as playing pivotal roles, while Figure 4 presents a

Table 1. Phenotypes associated with core pluripotency transcription factors

\begin{tabular}{|c|c|c|c|c|}
\hline $\begin{array}{l}\text { Transcription } \\
\text { factor }\end{array}$ & ESC overexpression & ESC loss of function & Embryo null & References \\
\hline Oct 4 & Differentiation & Differentiation to trophoblast & ICM becomes trophectoderm & Nichols et al. 1998; Niwa et al. 2000 \\
\hline Sox 2 & $\begin{array}{l}\text { May reduce } \\
\text { differentiation }\end{array}$ & $\begin{array}{l}\text { Differentiation to trophoblast; } \\
\text { rescued by Oct } 4\end{array}$ & Early postimplantation lethal & $\begin{array}{l}\text { Avilion et al. 2003; Masui et al. 2007; } \\
\text { Ura et al. } 2011\end{array}$ \\
\hline Nanog & $\begin{array}{l}\text { Autonomous self- } \\
\text { renewal }\end{array}$ & $\begin{array}{l}\text { Prone to differentiate, but can } \\
\text { self-renew }\end{array}$ & $\begin{array}{l}\text { Loss of epiblast and } \\
\text { secondarily of hypoblast }\end{array}$ & $\begin{array}{l}\text { Chambers et al. 2003, 2007; Mitsui } \\
\text { et al. 2003; Silva et al. } 2009\end{array}$ \\
\hline Stat3 & $\begin{array}{l}\text { Hormone- } \\
\text { activatable fusion } \\
\text { substitutes for } \\
\text { LIF }\end{array}$ & $\begin{array}{l}\text { No self-renewal in LIF, but } \\
\text { maintained in } 2 \mathrm{i}\end{array}$ & Postgastrulation lethal & $\begin{array}{l}\text { Takeda et al. 1997; Matsuda et al. } \\
\text { 1999; Ying et al. } 2008\end{array}$ \\
\hline Klf2 & $\begin{array}{l}\text { LIF-independent } \\
\text { self-renewal }\end{array}$ & Not certain (none by RNAi) & Viable & Jiang et al. 2008; Hall et al. 2009 \\
\hline Klf4 & $\begin{array}{l}\text { LIF-independent } \\
\text { self-renewal }\end{array}$ & Not certain (none by RNAi) & Viable & Jiang et al. 2008; Niwa et al. 2009 \\
\hline Esrrb & $\begin{array}{l}\text { LIF-independent } \\
\text { self-renewal }\end{array}$ & $\begin{array}{l}\text { Partially impaired self-renewal } \\
\text { (RNAi) }\end{array}$ & $\begin{array}{l}\text { Placental failure; midgestation } \\
\text { lethality }\end{array}$ & $\begin{array}{l}\text { Luo et al. 1997; Ivanova et al. 2006; } \\
\text { G Martello and AG Smith, unpubl. }\end{array}$ \\
\hline Tbx3 & $\begin{array}{l}\text { LIF-independent } \\
\text { self-renewal }\end{array}$ & $\begin{array}{l}\text { Partially impaired self-renewal } \\
\quad \text { (RNAi) }\end{array}$ & Midgestation lethality & $\begin{array}{l}\text { Davenport et al. 2003; Ivanova et al. } \\
\text { 2006; Niwa et al. } 2009\end{array}$ \\
\hline Tcf3 & Differentiation & Reduced LIF dependence & $\begin{array}{l}\text { Disrupted axial patterning; } \\
\text { gastrulation lethality }\end{array}$ & $\begin{array}{l}\text { Pereira et al. 2006; Guo et al. 2011; } \\
\text { Wray et al. } 2011\end{array}$ \\
\hline Mbd3 (NuRD) & Not described & Reduced LIF dependence & Early postimplantation lethal & Kaji et al. 2006, 2007 \\
\hline
\end{tabular}

Abbreviations: ICM, inner cell mass; LIF, leukemia inhibitor factor; RNAi, RNA interference. 
A Inner and outer core circuitry

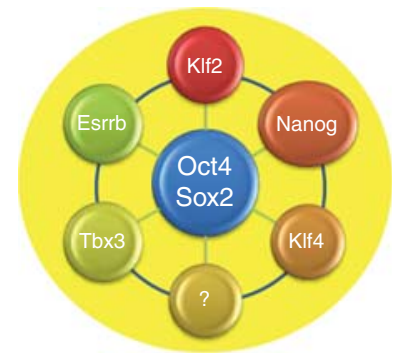

B Repressors and Erk target the outer circuit

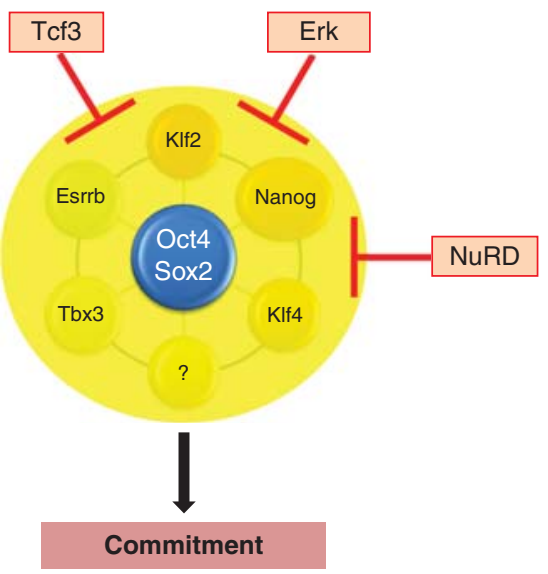

C 2i and LIF insulate and consolidate the outer circuit

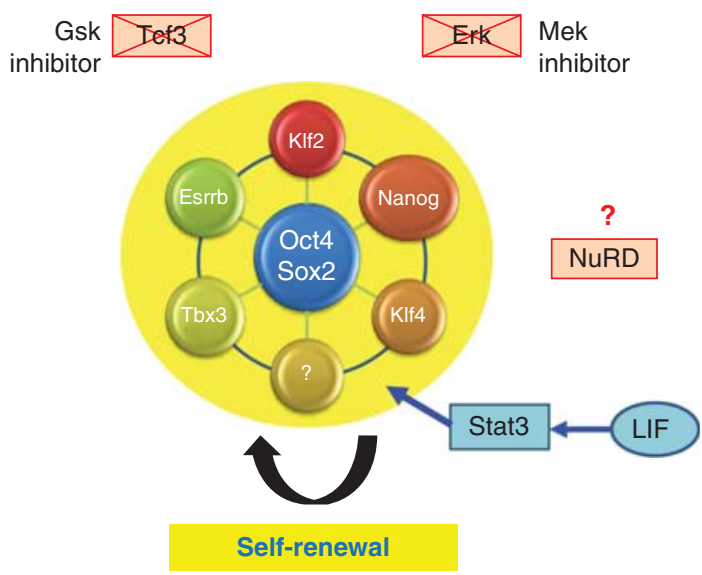

Figure 4. Illustration of the interconnections between core pluripotency transcription factors and extrinsic stimuli. (A) Schematic of the functionally validated pluripotency factors depicting Oct 4 and Sox 2 as the essential hub linked to a circuit of factors that are individually more or less dispensable but collectively define and sustain the naïve state. These factors all cross-regulate one another. The question mark signifies a hypothetical additional pivotal self-renewal factor downstream from Stat3. (B) Collapse of the outer circuit of pluripotency factors leads to exit from ground-state pluripotency and ultimately lineage commitment and differentiation. $(C)$. The $2 \mathrm{i}$ inhibitors prevent repression of the outer circuit, whereas LIF/Stat3 directly boosts expression of specific factors. How activity of NuRD is modulated in naïve ESCs is currently unclear. diagrammatic summary. Paramount among the pluripotency factors is Oct4. Oct4 is distinguished by its relatively uniform and continuous expression throughout formation and maturation of the epiblast, and in both ESCs and EpiSCs in culture. Using conventional serial gene targeting Oct4-null ESCs cannot be recovered. A conditional strategy that induces acute elimination of Oct4 in ESCs triggers their conversion predominantly into trophoblast-like cells (Niwa et al. 2000). Overexpression of Oct4 does not stabilize pluripotency, however, but drives differentiation instead. This has been interpreted as reflecting participation of Oct4 in diverse transcription factor complexes that differentially regulate gene expression and may contribute either to maintenance of pluripotency or to lineage specification (Niwa et al. 2000). Protein interaction studies are consistent with the expectation that Oct4 has multiple partners (Pardo et al. 2010; van den Berg et al. 2010).

The best-characterized Oct4 partner is Sox2. Cooperativity between Oct 4 and Sox 2 was first described based on their functional binding to an FGF4 enhancer element (Ambrosetti et al. 1997). An Oct/Sox element has subsequently been identified at many pluripotency genes (Chambers and Tomlinson 2009). Conditional deletion of Sox 2 in ESCs results in trophoblast differentiation, similar to deletion of Oct4 (Masui et al. 2007). Surprisingly, however, if Oct4 expression is maintained from a transgene, ESCs can be preserved in the absence of Sox 2 . The interpretation is that the only unique function of Sox 2 may be in activation of Oct 4 and that it may be substituted by alternative Sox proteins at other targets (Masui et al. 2007).

The variant homeodomain-containing protein, Nanog, was isolated in a functional cDNA screen in ESCs (Chambers et al. 2003). Overexpression of Nanog renders ESC selfrenewal constitutive without requirement for LIF, BMP, or 2i (Chambers et al. 2003; Ying et al. 2003, 2008; Hall et al. 2009). Nanog is essential for formation of the epiblast in the embryo, as discussed above, yet it can be deleted from ESCs. Nanog-null ESCs are highly prone to differentiation, but nonetheless can sustain self-renewal (Chambers et al. 2007). Furthermore, they are pluripotent and can contribute extensively to chimeras (Chambers et al. 2007). They even make primordial germ cells, although these fail to mature in the genital ridge.

In an effort to identify additional components required for ESC self-renewal, Ivanova and colleagues tested $>100$ transcription factors in an RNA interference loss-of-function screen (Ivanova et al. 2006). An inducible rescue strategy was used to exclude off-target effects. From this functional assay, six genes were implicated in maintenance of self-renewal. These include Oct4, Sox2, and Nanog, as expected. Also identified were the nuclear receptor Esrrb, T-box transcription factor-3 (Tbx3), and T-cell leukemia 
oncogene 1 ( $T c l 1)$. Esrrb has subsequently been found to interact with Oct4 and Nanog (van den Berg et al. 2008; Zhang et al. 2008) and to act as a reprogramming factor (Feng et al. 2009). However, during development Esrrb is required in the placenta, not in the embryo (Luo et al. 1997), suggesting that its function in pluripotent cells can be substituted by an alternative pathway. Tbx3 overexpression has been shown to enhance ESC self-renewal, and it is proposed to operate by activating Nanog downstream from phosphatidylinositol-3-kinase and Akt (Niwa et al. 2009). Tbx3 is also dispensable for early embryo development (Davenport et al. 2003). Tcll is implicated in activation of Akt and appears to be a direct target of Oct4 (Matoba et al. 2006). It is abundant in oocytes and during early cleavage but is not required for blastocyst formation or postimplantation development (Narducci et al. 2002).

A search for transcription factors downstream from LIF first suggested a role for the Kruppel-like factor Klf4 ( $\mathrm{Li}$ et al. 2005). Klf4 has been confirmed as a direct target of Stat3 (Bourillot et al. 2009; Hall et al. 2009) and when overexpressed can confer partial LIF independence to ESC propagation (Niwa et al. 2009). Klf4 does not fully reproduce the effect of LIF, however, indicating that additional Stat 3 targets contribute significantly. Interestingly, the related Klf2 is not regulated by LIF or Stat 3 but has similar, if not greater, capacity to support LIF-independent self-renewal (Hall et al. 2009). Embryos null for either Klf4 or Klf2 develop normally through gastrulation, and it is suggested that there may be substantial redundancy between the two factors (Jiang et al. 2008). The more distant relative Klf5 is required for blastocyst development (Ema et al. 2008), but its expression is not restricted to the ICM. Both deletion and overexpression of Klf5 produce only mild phenotypes in ESCs, suggesting that it does not serve a critical function in pluripotency.

Executing pluripotency requires exit from self-renewal and entry into lineage commitment guided by extrinsic cues (Smith 2009). Repressors that can suppress the pluripotency circuitry and drive ESCs out of the naïve state play a key role. One such factor is Tcf3, which, as previously discussed, functions by repressing key pluripotency factors, notably Esrrb, Klf2, and Nanog (Pereira et al. 2006; Cole et al. 2008; Guo et al. 2011; Wray et al. 2011). Tcf3-null ESCs are differentiation resistant (Pereira et al. 2006; Guo et al. 2011). Tcf3-null embryos develop normally until after implantation, when they show profound defects in axial patterning (Merrill et al. 2004). The nucleosome remodeling and deacetylase (NuRD) corepressor complex also plays a critical role in the exit from pluripotency. ESCs lacking NuRD owing to ablation of the scaffold protein Mbd3 differentiate inefficiently and fail to silence pluripotency genes (Kaji et al. 2006). In the absence of Mbd3, embryos become disorganized soon after implantation (Kaji et al. 2007).

The core gene regulatory network in ESCs is thus centered on Oct4 and Sox2, which are irreplaceable but are not capable of conferring self-renewal. A second group of transcription factors, which are individually dispensable, collectively sustain self-renewal (Fig. 4). These latter factors are expressed uniformly in $2 \mathrm{i}$ but are heterogeneous in serum (Chambers et al. 2007; Niwa et al. 2009). Unlike Oct4 they are down-regulated early during exit from the naïve state ( $\mathrm{T}$ Kalkan and AG Smith, unpubl.) and are absent or expressed at low levels in EpiSCs. In contrast, Oct4 and Sox 2 are present in all undifferentiated cells in serum and are maintained in EpiSCs. In serum, ESCs with low or absent expression of the outer factors may be susceptible to differentiation (Silva and Smith 2008; Smith 2009). Indeed, cells expressing low or undetectable levels of Nanog have a greater tendency to differentiate. However, some of these cells can reexpress Nanog and generate undifferentiated ESC colonies, so they are not yet committed (Chambers et al. 2007). It has been speculated that fluctuations in transcription factor expression may be an important feature of pluripotency that allows opportunity for lineage commitment (Graf and Stadtfeld 2008; Silva and Smith 2008). The lack of heterogeneity in $2 \mathrm{i}$, however, indicates that metastability is not an intrinsic property of self-renewing ESCs (Smith 2010; Wray et al. 2010). Whether it is a prerequisite for differentiation remains to be determined.

\section{EXPLOITING EMBRYONIC TRANSCRIPTION FACTORS TO CONVERT SOMATIC CELLS TO PLURIPOTENCY}

Candidate ESC regulators have also been selected using digital differential display to identify pluripotency-associated expression. A group of such genes, known as Ecats, were functionally evaluated by gene knockout. Nanog was independently identified from this study (Mitsui et al. 2003), and ERas was discovered as a Ras family member that promotes ESC expansion (Takahashi et al. 2003). The inspired application of the Ecats, however, was to attempt to recreate pluripotency (Takahashi and Yamanaka 2006). Multiple Ecats were retrovirally transduced into fibroblasts that were then exposed to ESC culture conditions. Selection was applied for activation of the ESC-specific Fbx15 promoter driving G418 resistance. Rare colonies were recovered, some of which morphologically resembled ESCs. By repeating this experiment and subtracting individual factors, a minimal group of four was found to be sufficient to reprogram fibroblasts to a pluripotent-like state. These are Oct4, Sox2, Klf4, and the oncogene c-Myc (Takahashi and Yamanaka 2006). The reprogrammed cells expressed 
endogenous ESC markers such as Oct4, Nanog, and ERas and were named induced pluripotent stem cells (iPSCs). Subsequently, by applying more rigorous selection for Nanog or Oct4 activation it was shown that a subset of iPSCs acquires authentic naïve pluripotency and can generate germline-competent chimeras (Okita et al. 2007; Wernig et al. 2007). Interestingly, the outer core pluripotency factors (Fig. 4), Nanog, Klf2, Esrrb, Tbx3, and Stat3, have each now been shown to contribute to reprogramming, although it is not clear to what extent these effects are redundant or additive.

\section{HUMAN PLURIPOTENT STEM CELLS}

The advent of iPSCs ignited ideas for potential medical applications. Disease-specific iPSCs may be used to dissect molecular mechanisms of disease progression and develop new pharmaceuticals, whereas patient-specific stem cells may one day provide a resource for autologous cell replacement therapies (Nishikawa et al. 2008; Yamanaka 2009). This requires human pluripotent stem cells, however.

The first primate pluripotent cell line was derived in 1995 from Rhesus macaque blastocysts (Thomson et al. 1995). In 1998, using donated supernumerary embryos from in vitro fertility treatment, human pluripotent cell lines were obtained (Thomson et al. 1998). They were designated as ESCs based on their origin from the blastocyst and capability to produce teratocarcinomas. However, closer investigation of these cells revealed a series of divergent properties compared with rodent ESCs (Chia et al. 2010). For example, the human cells do not respond functionally to LIF and self-renew in response to FGF and activin. These discrepancies were commonly attributed to species-specific differences. However, the derivation of EpiSCs from postimplantation mouse epiblasts (Brons et al. 2007; Tesar et al. 2007) supported the alternative explanation that the human cells represent a different developmental stage (Smith 2001). The process of derivation from primate embryos could involve progression in explant culture to the equivalent of a postimplantation state. As discussed above, primate epiblasts do not undergo egg cylinder morphogenesis, but expand in two dimensions as an embryonic disc. This pattern of development may proceed more readily in culture than egg cylinder morphogenesis. Moreover, mouse blastocysts cultured in FGF and activin produce EpiSCs rather than ESCs (Najm et al. 2011). It is now generally considered that current human pluripotent cells, whether embryo derived or generated by reprogramming, are more similar to EpiSCs than to ESCs. Like EpiSCs, they are heterogeneous between and within cell lines and can show marked biases in differentiation (Osafune et al. 2008). However, they show some molecular distinctions from EpiSCs, so the precise relationship is uncertain (Chia et al. 2010).

Efforts have been made to reprogram human cells into a naïve state. If transgene expression is continuous, cells can be obtained that show many properties of mouse ESCs, including two active $\mathrm{X}$ chromosomes, LIF responsiveness, and the ability to self-renew in 2i (Hanna et al. 2010; Wang et al. 2011). However, these cells appear difficult to maintain without transgene expression, and their relationship to authentic ESCs remains questionable at this point.

Studying the molecular regulation of epiblast development in human embryos may provide insights to enable the derivation of ESCs (Roode et al. 2012). It must also be recognized, however, that the facility for extrinsic stabilization of naïve pluripotency may be a rodent-specific phenomenon. In this case genetic bioengineering may be the route to capture and propagate a human naïve stem cell.

\section{CONCLUDING REMARKS}

ESCs are sustained by a flexible signaling and transcription factor network that appears to be closely based on circuitry operative in the embryo. Elucidation of the fundamental requirements for self-renewal has removed the genetic strain barrier to the efficient derivation of ESCs from mouse embryos and allowed production of the first germline-competent rat pluripotent cell lines, from both preimplantation embryos and primordial germ cells (Buehr et al. 2008; Li et al. 2008; Leitch et al. 2010; Blair et al. 2012). To date, however, there are no reports of authentic ESC lines from other mammals, indicating that additional components to $2 \mathrm{i}$ and LIF may be required. The notion of naïve pluripotency implies that early epiblast cells and their counterpart ESC derivatives have equal unrestricted access to all somatic lineages and the germline, whereas later epiblast cells and EpiSCs may be biased for particular lineage choices through transcriptional priming and/or chromatin modification. It will be instructive to identify genome-wide molecular correlates of the naive mouse ESC state at both transcriptome and epigenome levels. This may reveal expected constituents of a generic ground state.

\section{ACKNOWLEDGMENTS}

We thank all past and present members of the Nichols and Smith groups for their enthusiasm, endeavor, and insights. Austin Smith is a Medical Research Council Professor.

\section{REFERENCES}

Ambrosetti DC, Basilico C, Dailey L. 1997. Synergistic activation of the fibroblast growth factor 4 enhancer by Sox 2 and Oct-3 depends on protein-protein interactions facilitated by a specific spatial arrangement of factor binding sites. Mol Cell Biol 17: 6321-6329. 
Artus J, Piliszek A, Hadjantonakis AK. 2011. The primitive endoderm lineage of the mouse blastocyst: Sequential transcription factor activation and regulation of differentiation by Sox17. Dev Biol 350: $393-404$

Avilion AA, Nicolis SK, Pevny LH, Perez L, Vivian N, Lovell-Badge R. 2003. Multipotent cell lineages in early mouse development depend on SOX2 function. Genes Dev 17: 126-140.

Bao S, Tang F, Li X, Hayashi K, Gillich A, Lao K, Surani MA. 2009. Epigenetic reversion of post-implantation epiblast to pluripotent embryonic stem cells. Nature 461: 1292-1295.

Basilico C, Ambrosetti D, Fraidenraich D, Dailey L. 1997. Regulatory mechanisms governing FGF-4 gene expression during mouse development. J Cell Physiol 173: 227-232.

Batlle-Morera L, Smith A, Nichols J. 2008. Parameters influencing derivation of embryonic stem cells from murine embryos. Genesis 46: $758-767$.

Beddington RS, Robertson EJ. 1999. Axis development and early asymmetry in mammals. Cell 96: 195-209.

Berge DT, Kurek D, Blauwkamp T, Koole W, Maas A, Eroglu E, Siu RK, Nusse R. 2011. Embryonic stem cells require Wnt proteins to prevent differentiation to epiblast stem cells. Nat Cell Biol 13: 1070-1075.

Bernemann C, Greber B, Ko K, Sterneckert J, Han DW, Arauzo-Bravo MJ, Scholer HR. 2011. Distinct developmental ground states of epiblast stem cell lines determine different pluripotency features. Stem Cells 29: $1496-1503$.

Blair K, Leitch HG, Mansfield W, Dumeau CE, Humphreys P, Smith AG. 2012. Culture parameters for stable expansion, genetic modification and germline transmission of rat pluripotent stem cells. Biol Open doi: 10.1242/bio.2011029.

Bourillot PY, Aksoy I, Schreiber V, Wianny F, Schulz H, Hummel O, Hubner N, Savatier P. 2009. Novel STAT3 target genes exert distinct roles in the inhibition of mesoderm and endoderm differentiation in cooperation with Nanog. Stem Cells 27: 1760-1771.

Boyer LA, Lee TI, Cole MF, Johnstone SE, Levine SS, Zucker JP, Guenther MG, Kumar RM, Murray HL, Jenner RG, et al. 2005. Core transcriptional regulatory circuitry in human embryonic stem cells. Cell 122: 947-956.

Bradley A, Evans M, Kaufman MH, Robertson E. 1984. Formation of germ-line chimaeras from embryo-derived teratocarcinoma cell lines. Nature 309: 255-256.

Brons IG, Smithers LE, Trotter MW, Rugg-Gunn P, Sun B, Chuva de Sousa Lopes SM, Howlett SK, Clarkson A, Ahrlund-Richter L, Pedersen RA, et al. 2007. Derivation of pluripotent epiblast stem cells from mammalian embryos. Nature 448: 191-195.

Brook FA, Gardner RL. 1997. The origin and efficient derivation of embryonic stem cells in the mouse. Proc Natl Acad Sci 94: 5709-5712.

Brown MJ, Zogg JL, Schultz GS, Hilton FK. 1989. Increased binding of epidermal growth factor at preimplantation sites in mouse uteri. Endocrinology 124: 2882-2888.

Buehr M, Smith A. 2003. Genesis of embryonic stem cells. Philos Trans $R$ Soc Lond B Biol Sci 358: 1397-1402; discussion 1402.

Buehr M, Meek S, Blair K, Yang J, Ure J, Silva J, McLay R, Hall J, Ying QL, Smith A. 2008. Capture of authentic embryonic stem cells from rat blastocysts. Cell 135: 1287-1298.

Burdon T, Chambers I, Stracey C, Niwa H, Smith A. 1999. Signaling mechanisms regulating self-renewal and differentiation of pluripotent embryonic stem cells. Cells Tissues Organs 165: 131-143.

Capecchi MR. 2005. Gene targeting in mice: Functional analysis of the mammalian genome for the twenty-first century. Nat Rev Genet 6: $507-512$.

Cartwright P, McLean C, Sheppard A, Rivett D, Jones K, Dalton S. 2005. LIF/STAT3 controls ES cell self-renewal and pluripotency by a Mycdependent mechanism. Development 132: 885-896.

Chambers I, Tomlinson SR. 2009. The transcriptional foundation of pluripotency. Development 136: 2311-2322.
Chambers I, Colby D, Robertson M, Nichols J, Lee S, Tweedie S, Smith A. 2003. Functional expression cloning of Nanog, a pluripotency sustaining factor in embryonic stem cells. Cell 113: 643-655.

Chambers I, Silva J, Colby D, Nichols J, Nijmeijer B, Robertson M, Vrana J, Jones K, Grotewold L, Smith A. 2007. Nanog safeguards pluripotency and mediates germline development. Nature 450: 1230-1234.

Chazaud C, Yamanaka Y, Pawson T, Rossant J. 2006. Early lineage segregation between epiblast and primitive endoderm in mouse blastocysts through the Grb2-MAPK pathway. Dev Cell 10: 615-624.

Cheng AM, Saxton TM, Sakai R, Kulkarni S, Mbamalu G, Vogel W, Tortorice CG, Cardiff RD, Cross JC, Muller WJ, et al. 1998. Mammalian Grb2 regulates multiple steps in embryonic development and malignant transformation. Cell 95: 793-803.

Chia NY, Chan YS, Feng B, Lu X, Orlov YL, Moreau D, Kumar P, Yang L, Jiang J, Lau MS, et al. 2010. A genome-wide RNAi screen reveals determinants of human embryonic stem cell identity. Nature 468: $316-320$.

Chu LF, Surani MA, Jaenisch R, Zwaka TP. 2011. Blimp1 expression predicts embryonic stem cell development in vitro. Curr Biol 21: $1759-1765$.

Cole MF, Johnstone SE, Newman JJ, Kagey MH, Young RA. 2008. Tcf3 is an integral component of the core regulatory circuitry of embryonic stem cells. Genes Dev 22: 746-755.

Coucouvanis E, Martin GR. 1995. Signals for death and survival: A twostep mechanism for cavitation in the vertebrate embryo. Cell 83: 279-287.

Coucouvanis E, Martin GR. 1999. BMP signaling plays a role in visceral endoderm differentiation and cavitation in the early mouse embryo. Development 126: 535-546.

Das SK, Wang XN, Paria BC, Damm D, Abraham JA, Klagsbrun M, Andrews GK, Dey SK. 1994. Heparin-binding EGF-like growth factor gene is induced in the mouse uterus temporally by the blastocyst solely at the site of its apposition: A possible ligand for interaction with blastocyst EGF-receptor in implantation. Development 120: 10711083.

Davenport TG, Jerome-Majewska LA, Papaioannou VE. 2003. Mammary gland, limb and yolk sac defects in mice lacking $T b \times 3$, the gene mutated in human ulnar mammary syndrome. Development 130: $2263-2273$

Dietrich JE, Hiiragi T. 2007. Stochastic patterning in the mouse preimplantation embryo. Development 134: 4219-4231.

Ducibella T, Anderson E. 1975. Cell shape and membrane changes in the eight-cell mouse embryo: Prerequisites for morphogenesis of the blastocyst. Dev Biol 47: 45-58.

Eistetter HR. 1992. Pluripotent embryonal cell lines can be established from disaggregated mouse morulae. Dev Growth Diff 31: 275-282.

Ema M, Mori D, Niwa H, Hasegawa Y, Yamanaka Y, Hitoshi S, Mimura J, Kawabe Y, Hosoya T, Morita M, et al. 2008. Kruppel-like factor 5 is essential for blastocyst development and the normal self-renewal of mouse ESCs. Cell Stem Cell 3: 555-567.

Evans MJ, Kaufman M. 1981. Establishment in culture of pluripotential cells from mouse embryos. Nature 292: 154-156.

Feng B, Jiang J, Kraus P, Ng JH, Heng JC, Chan YS, Yaw LP, Zhang W, Loh $\mathrm{YH}, \mathrm{Han} \mathrm{J}$, et al. 2009. Reprogramming of fibroblasts into induced pluripotent stem cells with orphan nuclear receptor Esrrb. Nat Cell Biol 11: 197-203.

Graf T, Stadtfeld M. 2008. Heterogeneity of embryonic and adult stem cells. Cell Stem Cell 3: 480-483.

Guo G, Huss M, Tong GQ, Wang C, Li Sun L, Clarke ND, Robson P. 2010. Resolution of cell fate decisions revealed by single-cell gene expression analysis from zygote to blastocyst. Dev Cell 18: 675-685.

Guo G, Huang Y, Humphreys P, Wang X, Smith A. 2011. A PiggyBacbased recessive screening method to identify pluripotency regulators. PLoS ONE 6: e18189.

Hall J, Guo G, Wray J, Eyres I, Nichols J, Grotewold L, Morfopoulou S, Humphreys P, Mansfield W, Walker R, et al. 2009. Oct4 and LIF/Stat3 
additively induce Kruppel factors to sustain embryonic stem cell selfrenewal. Cell Stem Cell 5: 597-609.

Han DW, Tapia N, Joo JY, Greber B, Arauzo-Bravo MJ, Bernemann C, Ko K, Wu G, Stehling M, Do JT, et al. 2010. Epiblast stem cell subpopulations represent mouse embryos of distinct pregastrulation stages. Cell 143: 617-627.

Hanna J, Cheng AW, Saha K, Kim J, Lengner CJ, Soldner F, Cassady JP, Muffat J, Carey BW, Jaenisch R. 2010. Human embryonic stem cells with biological and epigenetic characteristics similar to those of mouse ESCs. Proc Natl Acad Sci 107: 9222-9227.

Hayashi K, Surani MA. 2009. Self-renewing epiblast stem cells exhibit continual delineation of germ cells with epigenetic reprogramming in vitro. Development 136: 3549-3556.

Hayashi K, Ohta H, Kurimoto K, Aramaki S, Saitou M. 2011. Reconstitution of the mouse germ cell specification pathway in culture by pluripotent stem cells. Cell 146: 519-532.

Ivanova N, Dobrin R, Lu R, Kotenko I, Levorse J, DeCoste C, Schafer X, Lun Y, Lemischka IR. 2006. Dissecting self-renewal in stem cells with RNA interference. Nature 442: 533-538.

Jaenisch R, Young R. 2008. Stem cells, the molecular circuitry of pluripotency and nuclear reprogramming. Cell 132: 567-582.

Jiang J, Chan YS, Loh YH, Cai J, Tong GQ, Lim CA, Robson P, Zhong S, $\mathrm{Ng} \mathrm{HH}$. 2008. A core Klf circuitry regulates self-renewal of embryonic stem cells. Nat Cell Biol 10: 353-360.

Johnson MH, Ziomek CA. 1981. The foundation of two distinct cell lineages within the mouse morula. Cell 24: 71-80.

Kaji K, Caballero IM, Macleod R, Nichols J, Wilson VA, Hendrich B. 2006. The NuRD component Mbd3 is required for pluripotency of embryonic stem cells. Nat Cell Biol 8: 285-292.

Kaji K, Nichols J, Hendrich B. 2007. Mbd3, a component of the NuRD co-repressor complex, is required for development of pluripotent cells. Development 134: 1123-1132.

Kanatsu-Shinohara M, Inoue K, Lee J, Yoshimoto M, Ogonuki N, Miki H, Baba S, Kato T, Kazuki Y, Toyokuni S, et al. 2004. Generation of pluripotent stem cells from neonatal mouse testis. Cell 119: 10011012.

Kiyonari H, Kaneko M, Abe S, Aizawa S. 2010. Three inhibitors of FGF receptor, ERK, and GSK3 establishes germline-competent embryonic stem cells of C57BL/ $6 \mathrm{~N}$ mouse strain with high efficiency and stability. Genesis 48: 317-327.

Ko K, Tapia N, Wu G, Kim JB, Bravo MJ, Sasse P, Glaser T, Ruau D, Han DW, Greber B, et al. 2009. Induction of pluripotency in adult unipotent germline stem cells. Cell Stem Cell 5: 87-96.

Koopman P, Cotton RG. 1984. A factor produced by feeder cells which inhibits embryonal carcinoma cell differentiation. Characterization and partial purification. Exp Cell Res 154: 233-242.

Kunath T, Saba-El-Leil MK, Almousailleakh M, Wray J, Meloche S, Smith A. 2007. FGF stimulation of the Erk1/2 signalling cascade triggers transition of pluripotent embryonic stem cells from self-renewal to lineage commitment. Development 134: 2895-2902.

Lawson KA, Meneses JJ, Pedersen RA. 1991. Clonal analysis of epiblast fate during germ layer formation in the mouse embryo. Development 113: 891-911.

Leitch HG, Blair K, Mansfield W, Ayetey H, Humphreys P, Nichols J, Surani MA, Smith A. 2010. Embryonic germ cells from mice and rats exhibit properties consistent with a generic pluripotent ground state. Development 137: 2279-2287.

Li Y, McClintick J, Zhong L, Edenberg HJ, Yoder MC, Chan RJ. 2005. Murine embryonic stem cell differentiation is promoted by SOCS-3 and inhibited by the zinc finger transcription factor Klf4. Blood 105: 635-637.

Li P, Tong C, Mehrian-Shai R, Jia L, Wu N, Yan Y, Maxson RE, Schulze EN, Song H, Hsieh CL, et al. 2008. Germline competent embryonic stem cells derived from rat blastocysts. Cell 135: 1299-1310.

Luo J, Sladek R, Bader JA, Matthyssen A, Rossant J, Giguere V. 1997. Placental abnormalities in mouse embryos lacking the orphan nuclear receptor ERR- $\beta$. Nature 388: 778-782.
Martin GR. 1981. Isolation of a pluripotent cell line from early mouse embryos cultured in medium conditioned by teratocarcinoma stem cells. Proc Natl Acad Sci 78: 7634-7638.

Martin GR, Evans MJ. 1975. Differentiation of clonal lines of teratocarcinoma cells: Formation of embryoid bodies in vitro. Proc Natl Acad Sci 72: 1441-1445.

Masui S, Nakatake Y, Toyooka Y, Shimosato D, Yagi R, Takahashi K, Okochi H, Okuda A, Matoba R, Sharov AA, et al. 2007. Pluripotency governed by Sox 2 via regulation of Oct3/4 expression in mouse embryonic stem cells. Nat Cell Biol 9: 625-635.

Matoba R, Niwa H, Masui S, Ohtsuka S, Carter MG, Sharov AA, Ko MS. 2006. Dissecting Oct3/4-regulated gene networks in embryonic stem cells by expression profiling. PLoS ONE 1: e26.

Matsuda T, Nakamura T, Nakao K, Arai T, Katsuki M, Heike T, Yokota T. 1999. STAT3 activation is sufficient to maintain an undifferentiated state of mouse embryonic stem cells. EMBO J 18: 4261-4269.

Matsui Y, Zsebo K, Hogan BLM. 1992. Derivation of pluripotential embryonic stem cells from murine primordial germ cells in culture. Cell 70: $841-847$.

Merrill BJ, Pasolli HA, Polak L, Rendl M, Garcia-Garcia MJ, Anderson KV, Fuchs E. 2004. Tcf3: A transcriptional regulator of axis induction in the early embryo. Development 131: 263-274.

Messerschmidt DM, Kemler R. 2010. Nanog is required for primitive endoderm formation through a non-cell autonomous mechanism. Dev Biol 344: 129-137.

Mitsui K, Tokuzawa Y, Itoh H, Segawa K, Murakami M, Takahashi K, Marauyama M, Maeda M, Yamanaka S. 2003. The homeoprotein Nanog is required for maintenance of pluripotency in mouse epiblast and ES cells. Cell 113: 631-642.

Nagy A, Gocza E, Diaz EM, Prideaux VR, Ivanyi E, Markkula M, Rossant J. 1990. Embryonic stem cells alone are able to support fetal development in the mouse. Development 110: 815-821.

Nagy A, Rossant J, Nagy R, Abramow-Newerly W, Roder JC. 1993. Derivation of completely cell culture-derived mice from early-passage embryonic stem cells. Proc Natl Acad Sci 90: 8424-8428.

Najm FJ, Chenoweth JG, Anderson PD, Nadeau JH, Redline RW, McKay RD, Tesar PJ. 2011. Isolation of epiblast stem cells from preimplantation mouse embryos. Cell Stem Cell 8: 318-325.

Narducci MG, Fiorenza MT, Kang SM, Bevilacqua A, Di Giacomo M, Remotti D, Picchio MC, Fidanza V, Cooper MD, Croce CM, et al. 2002. TCL1 participates in early embryonic development and is overexpressed in human seminomas. Proc Natl Acad Sci 99: 11712-11717.

Ng RK, Dean W, Dawson C, Lucifero D, Madeja Z, Reik W, Hemberger M. 2008. Epigenetic restriction of embryonic cell lineage fate by methylation of Elf5. Nat Cell Biol 10: 1280-1290.

Nichols J, Smith A. 2009. Naive and primed pluripotent states. Cell Stem Cell 4: 487-492.

Nichols J, Smith A. 2011. The origin and identity of embryonic stem cells. Development 138: 3-8.

Nichols J, Evans EP, Smith AG. 1990. Establishment of germ-line competent embryonic stem (ES) cells using differentiation inhibiting activity. Development 110: $1341-1348$.

Nichols J, Zevnik B, Anastassiadis K, Niwa H, Klewe-Nebenius D, Chambers I, Scholer H, Smith A. 1998. Formation of pluripotent stem cells in the mammalian embryo depends on the POU transcription factor Oct-4. Cell 95: 379-391.

Nichols J, Chambers I, Taga T, Smith A. 2001. Physiological rationale for responsiveness of mouse embryonic stem cells to gp130 cytokines. Development 128: 2333-2339.

Nichols J, Jones K, Phillips JM, Newland SA, Roode M, Mansfield W, Smith A, Cooke A. 2009a. Validated germline-competent embryonic stem cell lines from nonobese diabetic mice. Nat Med 15: 814-818.

Nichols J, Silva J, Roode M, Smith A. 2009b. Suppression of Erk signalling promotes ground state pluripotency in the mouse embryo. Development 136: 3215-3222. 
Nishikawa S, Goldstein RA, Nierras CR. 2008. The promise of human induced pluripotent stem cells for research and therapy. Nat Rev Mol Cell Biol 9: 725-729.

Nishioka N, Inoue K, Adachi K, Kiyonari H, Ota M, Ralston A, Yabuta N, Hirahara S, Stephenson RO, Ogonuki N, et al. 2009. The Hippo signaling pathway components Lats and Yap pattern Tead4 activity to distinguish mouse trophectoderm from inner cell mass. Dev Cell 16: $398-410$.

Niwa H. 2007. How is pluripotency determined and maintained? Development 134: 635-646.

Niwa H, Burdon T, Chambers I, Smith A. 1998. Self-renewal of pluripotent embryonic stem cells is mediated via activation of STAT3. Genes Dev 12: 2048-2060.

Niwa H, Miyazaki J, Smith AG. 2000. Quantitative expression of Oct-3/4 defines differentiation, dedifferentiation or self-renewal of ES cells. Nat Genet 24: 372-376.

Niwa H, Ogawa K, Shimosato D, Adachi K. 2009. A parallel circuit of LIF signalling pathways maintains pluripotency of mouse ES cells. Nature 460: $118-122$.

Ogawa K, Nishinakamura R, Iwamatsu Y, Shimosato D, Niwa H. 2006. Synergistic action of Wnt and LIF in maintaining pluripotency of mouse ES cells. Biochem Biophys Res Commun 343: 159-166.

Okita K, Ichisaka T, Yamanaka S. 2007. Generation of germline-competent induced pluripotent stem cells. Nature 448: 313-317.

Osafune K, Caron L, Borowiak M, Martinez RJ, Fitz-Gerald CS, Sato Y, Cowan CA, Chien KR, Melton DA. 2008. Marked differences in differentiation propensity among human embryonic stem cell lines. Nat Biotechnol 26: 313-315.

Pardo M, Lang B, Yu L, Prosser H, Bradley A, Babu MM, Choudhary J. 2010. An expanded Oct4 interaction network: Implications for stem cell biology, development, and disease. Cell Stem Cell 6: 382-395.

Pease S, Braghetta P, Gearing D, Grail D, Williams RL. 1990. Isolation of embryonic stem (ES) cells in media supplemented with recombinant leukemia inhibitory factor (LIF). Dev Biol 141: 344-352.

Pelton TA, Sharma S, Schulz TC, Rathjen J, Rathjen PD. 2002. Transient pluripotent cell populations during primitive ectoderm formation: Correlation of in vivo and in vitro pluripotent cell development. $J$ Cell Sci 115: 329-339.

Pereira L, Yi F, Merrill BJ. 2006. Repression of Nanog gene transcription by tcf3 limits embryonic stem cell self-renewal. Mol Cell Biol 26: 7479-7491.

Plusa B, Piliszek A, Frankenberg S, Artus J, Hadjantonakis AK. 2008. Distinct sequential cell behaviours direct primitive endoderm formation in the mouse blastocyst. Development 135: 3081-3091.

Resnick JL, Bixler LS, Cheng L, Donovan PJ. 1992. Long-term proliferation of mouse primordial germ cells in culture. Nature 359: 550-551.

Roode M, Blair K, Snell P, Elder K, Marchant S, Smith A, Nichols J. 2012. Human hypoblast formation is not dependent on FGF signalling. Dev Biol 36: 358-363.

Sato N, Meijer L, Skaltsounis L, Greengard P, Brivanlou AH. 2004. Maintenance of pluripotency in human and mouse embryonic stem cells through activation of Wnt signaling by a pharmacological GSK-3specific inhibitor. Nat Med 10: 55-63.

Selwood L, Johnson MH. 2006. Trophoblast and hypoblast in the monotreme, marsupial and eutherian mammal: Evolution and origins. Bioessays 28: $128-145$.

Silva J, Smith A. 2008. Capturing pluripotency. Cell 132: 532-536.

Silva J, Nichols J, Theunissen TW, Guo G, van Oosten AL, Barrandon O, Wray J, Yamanaka S, Chambers I, Smith A. 2009. Nanog is the gateway to the pluripotent ground state. Cell 138: 722-737.

Smith AG. 2001. Embryo-derived stem cells: Of mice and men. Annu Rev Cell Dev Biol 17: 435-462.

Smith A. 2009. Design principles of pluripotency. EMBO Mol Med 1: $251-254$.

Smith A. 2010. Pluripotent stem cells: Private obsession and public expectation. EMBO Mol Med 2: 113-116.
Smith TA, Hooper ML. 1983. Medium conditioned by feeder cells inhibits the differentiation of embryonal carcinoma cultures. Exp Cell Res 145: $458-462$.

Smith AG, Hooper ML. 1987. Buffalo rat liver cells produce a diffusible activity which inhibits the differentiation of murine embryonal carcinoma and embryonic stem cells. Dev Biol 121: 1-9.

Smith AG, Heath JK, Donaldson DD, Wong GG, Moreau J, Stahl M, Rogers D. 1988. Inhibition of pluripotential embryonic stem cell differentiation by purified polypeptides. Nature 336: 688-690.

Sokol SY. 2011. Maintaining embryonic stem cell pluripotency with Wnt signaling. Development 138: 4341-4350.

Solter D, Skreb N, Damjanov I. 1970. Extrauterine growth of mouse egg cylinders results in malignant teratoma. Nature 227: 503-504.

Stavridis MP, Lunn JS, Collins BJ, Storey KG. 2007. A discrete period of FGF-induced Erk1/2 signalling is required for vertebrate neural specification. Development 134: 2889-2894.

Stevens LC. 1970. The development of transplantable teratocarcinomas from intratesticular grafts of pre- and postimplantation mouse embryos. Dev Biol 21: 364-382.

Takahashi K, Yamanaka S. 2006. Induction of pluripotent stem cells from mouse embryonic and adult fibroblast cultures by defined factors. Cell 126: $663-676$.

Takahashi K, Mitsui K, Yamanaka S. 2003. Role of ERas in promoting tumour-like properties in mouse embryonic stem cells. Nature 423: 541-545.

Takeda K, Noguchi K, Shi W, Tanaka T, Matsumoto M, Yoshida N, Kishimoto T, Akira S. 1997. Targeted disruption of the mouse Stat3 gene leads to early embryonic lethality. Proc Natl Acad Sci 94: 3801-3804.

Tarkowski AK, Wroblewska J. 1967. Development of blastomeres of mouse eggs isolated at the four- and eight-cell stages. J Embryol Exp Morphol 18: 155-180.

ten Berge D, Koole W, Fuerer C, Fish M, Eroglu E, Nusse R. 2008. Wnt signaling mediates self-organization and axis formation in embryoid bodies. Cell Stem Cell 3: 508-518.

Tesar PJ. 2005. Derivation of germ-line-competent embryonic stem cell lines from preblastocyst mouse embryos. Proc Natl Acad Sci 102: $8239-8244$.

Tesar PJ, Chenoweth JG, Brook FA, Davies TJ, Evans EP, Mack DL, Gardner RL, McKay RD. 2007. New cell lines from mouse epiblast share defining features with human embryonic stem cells. Nature 448: 196-199.

Thomson JA, Kalishman J, Golos TG, Durning M, Harris CP, Becker RA, Hearn JP. 1995. Isolation of a primate embryonic stem cell line. Proc Natl Acad Sci 92: 7844-7848.

Thomson JA, Itskovitz-Eldor J, Shapiro SS, Waknitz MA, Swiergiel JJ, Marshall VS, Jones JM. 1998. Embryonic stem cell lines derived from human blastocysts. Science 282: 1145-1147.

Ura H, Murakami K, Akagi T, Kinoshita K, Yamaguchi S, Masui S, Niwa H, Koide H, Yokota T. 2011. Eed/Sox2 regulatory loop controls ES cell self-renewal through histone methylation and acetylation. EMBO J 30: 2190-2204.

van den Berg DL, Zhang W, Yates A, Engelen E, Takacs K, Bezstarosti K, Demmers J, Chambers I, Poot RA. 2008. Estrogen-related receptor $\beta$ interacts with Oct4 to positively regulate Nanog gene expression. Mol Cell Biol 28: 5986-5995.

van den Berg DLC, Snoek T, Mullin NP, Yates A, Bezstarosti K, Demmers J, Chambers I, Poot RA. 2010. An Oct4-centered protein interaction network in embryonic stem cells. Cell Stem Cell 6: 369-381.

Wada K, Itoga K, Okano T, Yonemura S, Sasaki H. 2011. Hippo pathway regulation by cell morphology and stress fibers. Development 138: 3907-3914.

Wang W, Yang J, Liu H, Lu D, Chen X, Zenonos Z, Campos LS, Rad R, Guo G, Zhang S, et al. 2011. Rapid and efficient reprogramming of somatic cells to induced pluripotent stem cells by retinoic acid receptor $\gamma$ and liver receptor homolog 1. Proc Natl Acad Sci 108: $18283-18288$. 
Wernig M, Meissner A, Foreman R, Brambrink T, Ku M, Hochedlinger K, Bernstein BE, Jaenisch R. 2007. In vitro reprogramming of fibroblasts into a pluripotent ES-cell-like state. Nature 448: 318-324.

Williams RL, Hilton DJ, Pease S, Willson TA, Stewart CL, Gearing DP, Wagner EF, Metcalf D, Nicola NA, Gough NM. 1988. Myeloid leukaemia inhibitory factor maintains the developmental potential of embryonic stem cells. Nature 336: 684-687.

Wray J, Kalkan T, Smith AG. 2010. The ground state of pluripotency. Biochem Soc Trans 38: 1027-1032.

Wray J, Kalkan T, Gomez-Lopez S, Eckardt D, Cook A, Kemler R, Smith A. 2011. Inhibition of glycogen synthase kinase-3 alleviates Tcf3 repression of the pluripotency network and increases embryonic stem cell resistance to differentiation. Nat Cell Biol 13: 838845.

Yamagata K, Ueda J, Mizutani E, Saitou M, Wakayama T. 2010. Survival and death of epiblast cells during embryonic stem cell derivation revealed by long-term live-cell imaging with an Oct4 reporter system. Dev Biol 346: 90-101.
Yamanaka S. 2009. A fresh look at iPS cells. Cell 137: 13-17.

Yamanaka Y, Lanner F, Rossant J. 2010. FGF signal-dependent segregation of primitive endoderm and epiblast in the mouse blastocyst. Development 137: 715-724.

Yi F, Pereira L, Hoffman JA, Shy BR, Yuen CM, Liu DR, Merrill BJ. 2011. Opposing effects of Tcf3 and Tcf1 control Wnt stimulation of embryonic stem cell self-renewal. Nat Cell Biol 13: 762-770.

Ying QL, Nichols J, Chambers I, Smith A. 2003. BMP induction of Id proteins suppresses differentiation and sustains embryonic stem cell self-renewal in collaboration with STAT3. Cell 115: 281-292.

Ying QL, Wray J, Nichols J, Batlle-Morera L, Doble B, Woodgett J, Cohen P, Smith A. 2008. The ground state of embryonic stem cell self-renewal. Nature 453: 519-523.

Zhang X, Zhang J, Wang T, Esteban MA, Pei D. 2008. Esrrb activates Oct4 transcription and sustains self-renewal and pluripotency in embryonic stem cells. J Biol Chem 283: 35825-35833.

Zwaka TP, Thomson JA. 2005. A germ cell origin of embryonic stem cells? Development 132: 227-233. 


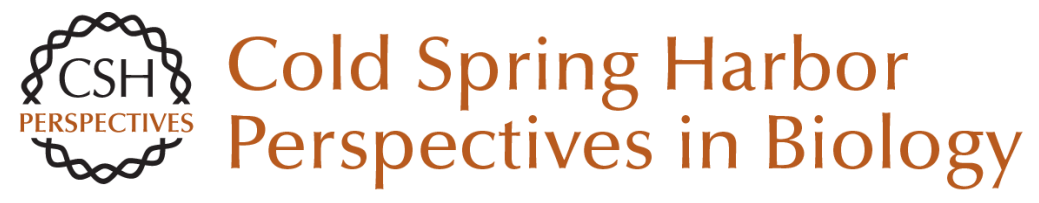

\section{Pluripotency in the Embryo and in Culture}

Jennifer Nichols and Austin Smith

Cold Spring Harb Perspect Biol 2012; doi: 10.1101/cshperspect.a008128

Subject Collection Mammalian Development

The Dynamics of Morphogenesis in the Early Mouse Embryo

Jaime A. Rivera-Pérez and Anna-Katerina Hadjantonakis

microRNAs as Developmental Regulators Kathryn N. Ivey and Deepak Srivastava

Development of the Endochondral Skeleton Fanxin Long and David M. Ornitz

Adipogenesis Kelesha Sarjeant and Jacqueline M. Stephens

Molecular Mechanisms of Inner Ear Development Doris K. Wu and Matthew W. Kelley

Polarity in Mammalian Epithelial Morphogenesis Julie Roignot, Xiao Peng and Keith Mostov

Eye Development and Retinogenesis Whitney Heavner and Larysa Pevny

Primordial Germ Cells in Mice Mitinori Saitou and Masashi Yamaji
Cell Division Modes and Cleavage Planes of Neural Progenitors during Mammalian Cortical Development

Fumio Matsuzaki and Atsunori Shitamukai

Blood and Lymphatic Vessel Formation Victoria L. Bautch and Kathleen M. Caron

Transcriptional Networks in Liver and Intestinal

Development Karyn L. Sheaffer and Klaus H. Kaestner

Pluripotency in the Embryo and in Culture Jennifer Nichols and Austin Smith

Signaling and Transcriptional Networks in Heart Development and Regeneration Benoit G. Bruneau

Signals and Switches in Mammalian Neural Crest Cell Differentiation Shachi Bhatt, Raul Diaz and Paul A. Trainor

Hematopoiesis Michael A. Rieger and Timm Schroeder

Intercellular Interactions, Position, and Polarity in Establishing Blastocyst Cell Lineages and Embryonic Axes Robert O. Stephenson, Janet Rossant and Patrick P.L. Tam

For additional articles in this collection, see http://cshperspectives.cshlp.org/cgi/collection/

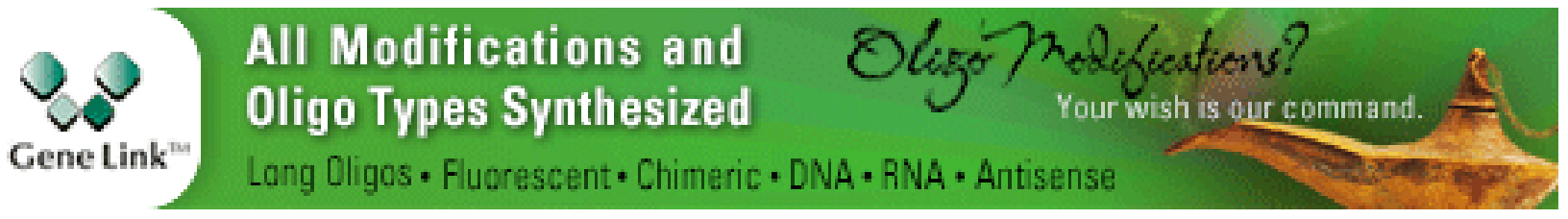

Copyright (C 2012 Cold Spring Harbor Laboratory Press; all rights reserved 